\title{
Hyperglucagonemia of Renal Failure
}

\author{
Gordon L. Bilbrey, Gerald R. Faloona, Martin G. White, and \\ JAMES P. KNOCHEL, with the technical assistance of JULIo BorRoTo \\ From the Veterans Administration Hospital, Dallas, Texas 75216 and the \\ University of Texas Southwestern Medical School, Dallas, Texas 75235
}

A B S T R A C T Elevation of plasma glucagon concentration has been observed in starvation and illnesses associated with increased catabolism such as diabetes mellitus and severe infections. Thus, we examined plasma glucose, immunoreactive insulin (IRI, microunits per milliliter) and glucagon (IRG, picograms per milliliter) responses to a beef meal ( $1 \mathrm{~g} / \mathrm{kg}$ body wt) and intravenous glucose $(1.5 \mathrm{~g} / \mathrm{min}$ for $45 \mathrm{~min})$ in patients with chronic renal failure (CRF).

After the beef meal $(n=6)$, plasma glucose did not change, IRI rose from $10.1 \pm 1.2$ to $16.3 \pm 1.1(P<0.01)$, and IRG rose from a fasting value of $225 \pm 26$ to $321 \pm 40$ $(P<0.01)$ by 90 min (mean \pm SEM).

Intravenous infusion of glucose in CRF patients resulted in significant elevations and prolonged disappearance of plasma glucose and insulin when compared to control subjects $(P<0.01)$. Glucose infusion failed to suppress elevated plasma glucagon concentrations to normal levels.

$6 \mathrm{wk}$ of chronic hemodialysis in five patients resulted in normal plasma glucose and insulin responses to the same intravenous glucose load. In contrast, plasma glucagon concentration remained unchanged after hemodialysis and there was no correlation of plasma glucagon levels with carbohydrate intolerance.

\section{INTRODUCTION}

It has been appreciated for many years (1) that patients with uremia are generally unable to utilize carbohydrate normally. Characteristically, either oral or intravenous glucose loads are followed by hyperglycemia and delayed return of blood glucose values to normal. These patients seldom have fasting hyperglycemia or ketosis (2). Fasting plasma insulin concentration and response of plasma insulin to glucose loads in uremic patients

This work was presented in part at the International Society of Nephrology, Mexico City, 11 October 1972 and the Central Society for Clinical Investigation, Chicago, Ill., 22 November 1972.

Received for publication 23 May 1973 and in revised form 20 September 1973. have been studied by several investigators (3-11). While most have found normal or increased plasma insulin concentration in the fasting state $(4,6,9,10)$, the subsequent response to hyperglycemia has been reported to be blunted $(4,6,7)$ or increased $(8-10)$. There is general agreement, however, that uremic patients demonstrate decreased responsiveness to exogenous insulin $(4,12,13)$ and prolongation of plasma disappearance time of injected ${ }^{131} I$-labeled insulin $(6,14)$. A serum inhibitor interfering with the metabolism of carbohydrate or the action of insulin has been postulated $(4,7,10)$. This has been assumed to be dialyzable since adequate therapy leads to improvement in glucose tolerance (4).

Additional factors considered by many investigators to be important in the pathogenesis of carbohydrate intolerance in uremia include interference with glucose phosphorylation $(13,15)$, potassium deficiency (16), accumulation of urea, creatinine, ammonia, and guanidine derivatives (17), systemic acidosis (18) and peripheral insulin resistance (13).

This study was designed to examine pancreatic beta and alpha cell function in patients with chronic renal failure $(C R F)^{1}$ with the intent of elucidating the possible role of insulin and glucagon in the glucose intolerance of uremia. In normal subjects, plasma glucagon responses to oral and intravenous carbohydrate and protein stimuli have been well defined by Unger and his associates (19-21). In contrast, plasma glucagon levels, measured by radioimmunoassay methods specific for pancreatic glucagon, have not been reported in uremic subjects. Thus, responses of plasma glucose, insulin, and glucagon to an oral protein meal and intravenous glucose infusion were examined in uremic patients. The responses to glucose infusion were measured before and after hemodialysis. Because of its known influence on carbohydrate metabolism, the plasma growth hormone $(\mathrm{GH})$ response to intravenous glucose loads was also examined.

\footnotetext{
1 Abbreviations used in this paper: CFR, chronic renal failure; GH, growth hormone; IRG, immunoreactive glucagon.
} 
TABLE I

Clinical Parameters of $C R F$

\begin{tabular}{|c|c|c|c|c|c|c|c|c|}
\hline Patient & Age & Venous pH & BUN & $\begin{array}{l}\text { Serum } \\
\mathbf{K}\end{array}$ & $\begin{array}{c}\text { Serum } \\
\text { Creatinine }\end{array}$ & Diagnosis & $\begin{array}{l}\text { Serum } \\
\text { Albumin }\end{array}$ & Edema \\
\hline & $y r$ & & $m g / 100 m l$ & meq/liter & $m g / 100 m l$ & & $\mathrm{~g} / 100 \mathrm{ml}$ & \\
\hline L. C. & 44 & 7.40 & 96 & 5.3 & 12.1 & C.G.N. & 3.7 & None \\
\hline C. $\mathrm{H}$. & 43 & 7.41 & - & 3.9 & 6.3 & Nephrosclerosis & 3.4 & None \\
\hline W. R. & 31 & 7.39 & 69 & 3.4 & 8.7 & $\begin{array}{l}\text { C.G.N. and hypo- } \\
\text { plastic rt. kidney }\end{array}$ & 4.8 & None \\
\hline A. L. & 48 & 7.39 & 100 & 5.4 & 16.8 & C.G.N. & 3.7 & Moderate \\
\hline W. H. & 59 & 7.47 & 165 & 3.3 & 18.0 & Nephrosclerosis & 3.4 & Mild \\
\hline E. P. & 49 & 7.32 & 125 & 5.5 & 13.5 & C.G.N. & 4.1 & Moderate \\
\hline P. S. & 56 & 7.35 & 132 & 7.4 & 28.4 & Nephrosclerosis & 2.6 & Mild \\
\hline H. G. & 35 & 7.33 & 45 & 5.0 & 8.6 & C.G.N. & 3.8 & None \\
\hline W. D. & 54 & - & 105 & 4.9 & 23.2 & Nephrosclerosis & 3.5 & Mild \\
\hline J. O. & 64 & - & 107 & 3.9 & 10.4 & Nephrosclerosis & 4.0 & Mild \\
\hline W. M. & 54 & - & 64 & 5.1 & 7.3 & Polycystic & 4.4 & None \\
\hline J. H. & 35 & - & 60 & 4.8 & 9.6 & C.G.N. & 3.7 & None \\
\hline E. S. & 50 & 一 & 82 & 5.0 & 20.6 & Nephrosclerosis & 3.1 & Mild \\
\hline E. K. & 60 & 7.50 & 151 & 3.7 & 15.7 & $\begin{array}{l}\text { Diabetes and } \\
\text { nephrosclerosis }\end{array}$ & 3.8 & None \\
\hline C. B. & 45 & 7.43 & 37 & 3.8 & 4.0 & C.G.N. & 4.8 & None \\
\hline
\end{tabular}

BUN, blood urea nitrogen; C.G.N., chronic glomerulonephritis.

\section{METHODS}

Subjects. 15 stable CRF patients attending the outpatient renal clinic of the Dallas Veterans Administration Hospital received an intravenous glucose infusion or an oral protein meal; three patients received both on separate occasions. All patients were male and overt diabetes was not apparent in any patient except one (E. K.), who had a 15-yr history of diabetes mellitus, managed by diet alone. Pertinent clinical data for each patient are outlined in Table I. 10 normal male subjects, recruited from physicians and technicians of the Dallas Veterans Administration Hospital, served as controls. Mean age of the control subjects was $35 \mathrm{yr}$ (range, 20-59).

Procedures. All subjects reported to the renal-metabolic unit at 8:00 a.m. after an overnight fast. Patients were instructed to omit all medications the morning of the test.

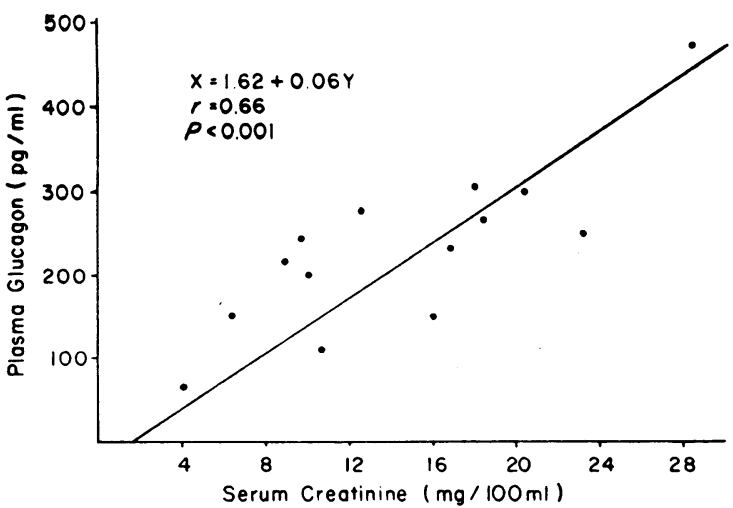

Figure 1 Correlation of serum creatinine and plasma glucagon concentrations in patients with $\mathrm{CRF}$.
Six CRF patients and seven controls consumed a beef meal consisting of $1 \mathrm{~g}$ of lean beef $/ \mathrm{kg}$ of body wt. Control and experimental plasma samples were obtained from each subject and analyzed for glucose, insulin, and glucagon.

$12 \mathrm{CRF}$ and six normal subjects received an intravenous infusion of $10 \%$ glucose at the rate of $1.5 \mathrm{~g} / \mathrm{min}$ for $45 \mathrm{~min}$. Daily dietary intake of carbohydrate was $300 \mathrm{~g}$ for 3 days before testing in all subjects, whereas the oral protein intake of CRF patients was mildly restricted (40 g/day). Control and sequential experimental plasma samples were obtained from each subject and analyzed for glucose, insulin, glucagon, and GH. Six of the $12 \mathrm{CRF}$ patients were studied before and again after hemodialysis.

Glucose was measured by a modification of the procedure of Brown (22), using the Technicon Autoanalyzer (Technicon Instruments Corp., Tarrytown, N. Y.). Immunoreactive plasma glucagon and insulin were determined as previously described (19). Rabbit anti-glucagon serum G58 was used for the human studies and antiserum $30 \mathrm{~K}$ for the dog experiments. Both antisera are highly specific for pancreatic glucagon. Radioimmunoassay of $\mathrm{GH}$ was graciously performed by Dr. Holbrooke Seltzer.

Animal studies. Bilateral ureteral ligation was performed on six dogs in an attempt to reproduce uremic hyperglucagonemia and assess its rapidity of onset. Three additional dogs served as sham-operated controls. In 12 additional dogs, serial measurements of plasma glucagon were obtained during intravenous infusions of urea $(n=6)$ or creatinine $(n=6)$.

\section{RESULTS}

\section{Comparison of fasting plasma glucagon and serum creatinine concentrations}

The normal range of fasting plasma glucagon in our 10 control subjects was $48-125$ with a mean of $103 \pm 5.4$ 


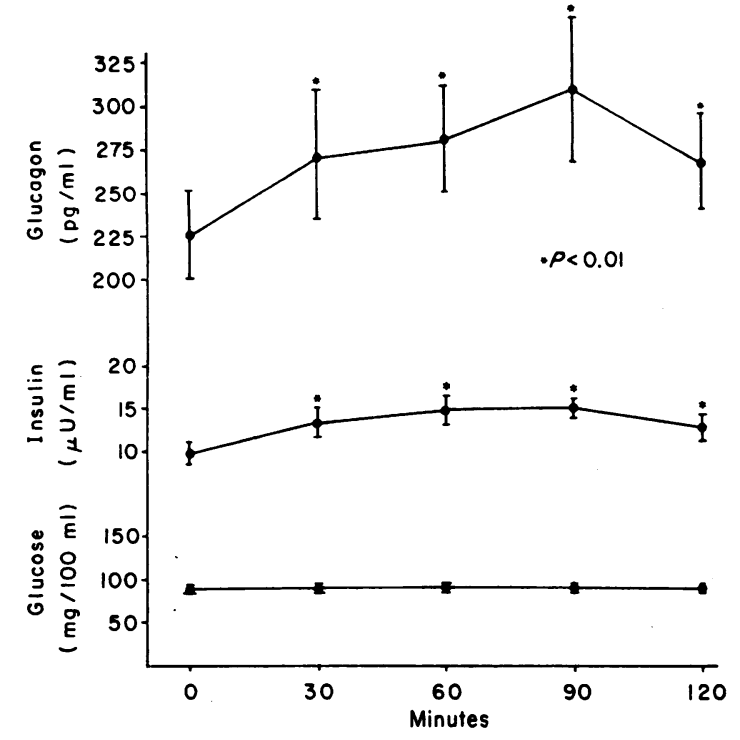

FIgURE 2 Response of CRF patients to oral protein meal consumed immediately after procurement of control samples at zero time.

$\mathrm{pg} / \mathrm{ml}$, SEM. In contrast, 12 of 14 patients with CRF exceeded the normal range and the mean fasting plasma glucagon was $228 \pm 25 \mathrm{pg} / \mathrm{ml}$, SEM, a value significantly elevated from normal $(P<0.001)$. There was a significant correlation $(r=0.66, P<0.001)$ of serum creatinine with plasma glucagon concentrations (Fig. 1).

\section{Hormonal responses to ingested protein}

Normal subjects. The response of plasma glucose, insulin, and glucagon to a protein meal has been previously described (21) and by comparison the quantity of protein ingested by our normal subjects was considerably less. Even so, significant $(P<0.01)$ peak increases of insulin $(10.9 \pm 1.6-16.9 \pm 3.2 \mu \mathrm{U} / \mathrm{ml}, \mathrm{SEM})$ and glucagon (105 $\pm 7.4-129 \pm 5.6 \mathrm{pg} / \mathrm{ml}, \mathrm{SEM}$ ) occurred, each subject serving as his own control. Plasma glucose concentrations showed no significant change.

$C R F$ patients. The average fasting level of plasma glucagon in this group of patients $(n=6)$ was $227 \pm 26$ $\mathrm{pg} / \mathrm{ml}, \mathrm{SEM}$. The peak glucagon response to protein ingestion $(310 \mathrm{pg} / \mathrm{ml}$ ) occurred at $90 \mathrm{~min}$ (Fig. $2, P<$ 0.01 ). Mean plasma insulin concentration was significantly increased by protein ingestion $(P<0.01)$. The magnitude of response was similar to and not significantly different from controls. Plasma glucose concentration was unchanged.

\section{Hormonal responses to glucose infusion}

Plasma glucose. The previous studies of intravenous glucose infusions in uremic patients cited above have demonstrated a delayed apogee and prolonged disappear- ance rate of plasma glucose concentrations. Comparison of CRF and normal subjects confirmed this response. In normal subjects, plasma glucose concentrations at 90 , 120 , and $180 \mathrm{~min}$ were $148 \pm 20,91 \pm 10$, and $64 \pm 3 \mathrm{mg} /$ $100 \mathrm{ml} \mathrm{SEM}$, respectively. In contrast, comparable values in patients with CRF were $221 \pm 22,179 \pm 23$, and $119 \pm 19$. All differences were highly significant $(P<$ 0.01 ).

Plasma insulin. Normal fasting plasma insulin followed by abnormally high plasma concentrations and prolonged plasma insulin disappearance time in response to glucose infusion has been previously reported in CRF patients $(6,9,23)$. Mean fasting insulin levels of $\mathrm{CRF}$ and normal subjects were $11.4 \pm 2.3$ and $8.8 \pm 1.9$ $\mu \mathrm{U} / \mathrm{ml}$, SEM. The difference between these values is not statistically significant. However, the peak plasma insulin response to the same magnitude of hyperglycemia was markedly accentuated in CRF subjects, the mean peak value obtained being $142 \pm 22$ compared to $62 \pm 7$ $\mu \mathrm{U} / \mathrm{ml}, \mathrm{SEM}$, in normal subjects $(P<0.01)$.

Plasma glucagon. Previous studies have clearly demonstrated the suppression of plasma glucagon concentrations with glucose infusion (20). Six normal subjects showed a similar response; their mean fasting plasma glucagon concentration of $85 \pm 9.1$ was suppressed to a low of $57 \pm 9.8, \mathrm{SEM}$, at $60 \mathrm{~min}$ (Fig. 3). In these experiments, hyperglucagonemia in $\mathrm{CRF}$ was again clearly evident. The mean fasting plasma concentration of 10 patients was $250 \pm 32 \mathrm{pg} / \mathrm{ml}$, SEM. Plasma glucagon fell to a minimum value of $189 \pm 29$ at $120 \mathrm{~min}$, a value still significantly above normal plasma concentrations.

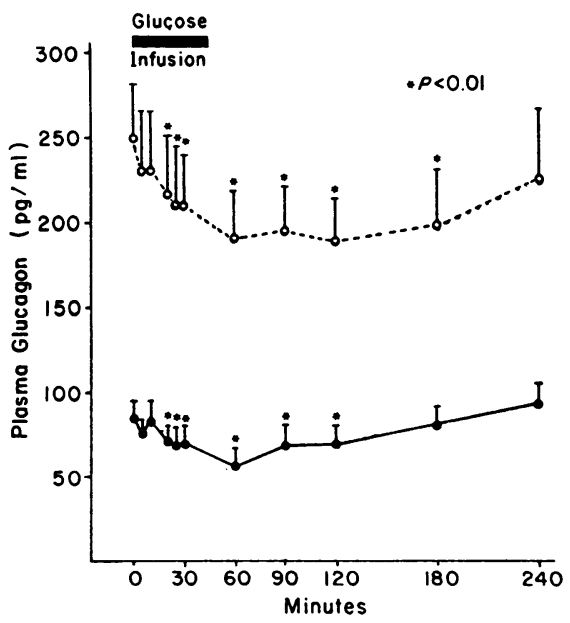

Figure 3 All values are depicted as the mean \pm SEM. Normal subjects are represented by the solid circles and CRF patients by the open circles. The asterisk symbols represent a significant decrease from control by paired analysis. 

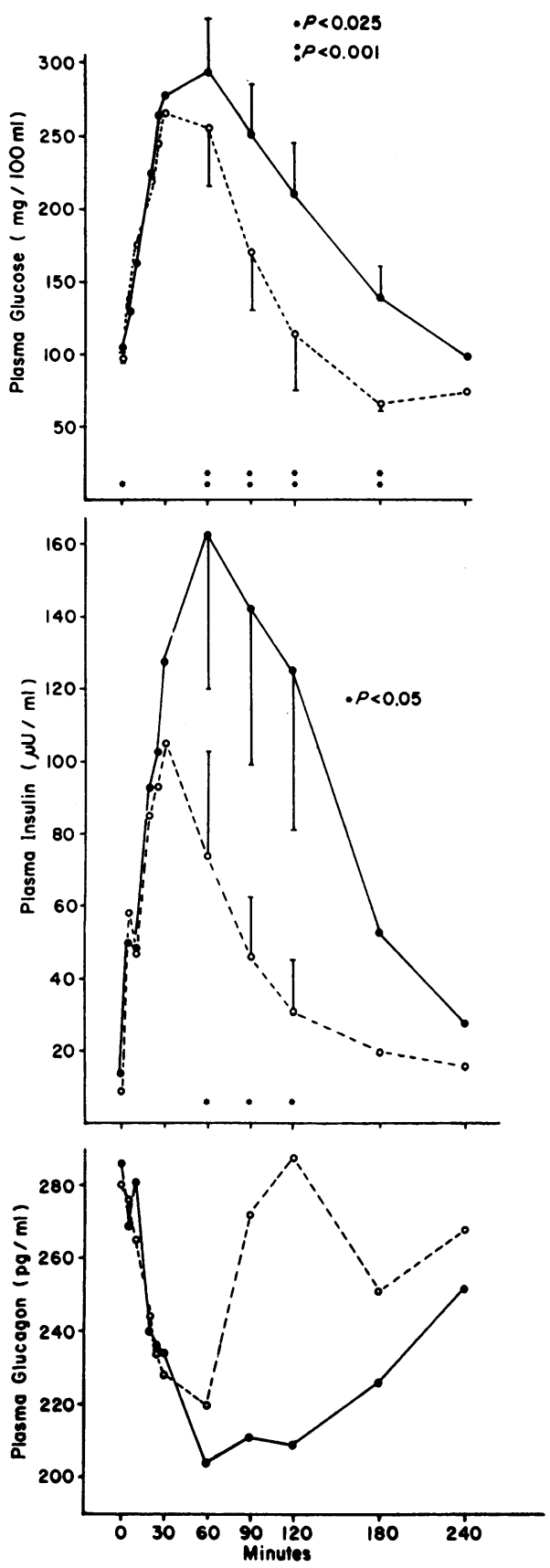

Figure 4 Five CRF patients who received glucose infusion (0-45 min) before (solid circles) and after (open circles) $6 \mathrm{wk}$ of hemodialysis. Asterisk symbols represented significant differences by paired $t$ analysis.

Growth hormone. Suppression of plasma GH concentrations in normal individuals with intravenous glucose infusion is well documented (24). In approximately $60 \%$ of patients with $\mathrm{CRF}$, fasting $\mathrm{GH}$ is abnormally elevated and, paradoxically, rises during glucose infusion $(25-27)$. Our studies reconfirm this observation.
Plasma GH was measured during glucose infusion in nine CRF patients and six normal controls. Five pa-

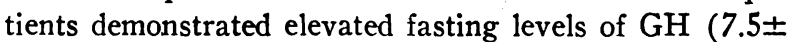
1.3 ) which significantly rose $(P<0.01)$ at $60 \mathrm{~min}$. Respective values in normal subjects were $0.6 \pm 0.2$ and $0.2 \pm 0.1 \mathrm{ng} / \mathrm{ml}$. The remaining four CRF patients tested had normal fasting levels of $\mathrm{GH}$ and the response to glucose infusion was similar to control subjects. In accord with previous observations (25) there was no relationship of plasma $\mathrm{GH}$ concentrations to the presence or absence of carbohydrate intolerance. Indeed, normal $\mathrm{GH}$ levels were observed in patient $\mathrm{L}$. C. who demonstrated the most severe glucose intolerance.

Effect of hemodialysis on carbohydrate tolerance and plasma glucagon, insulin, and $\mathrm{GH}$

The disappearance of carbohydrate intolerance after a minimum of 2 wk of hemodialysis was described by Hampers, Soeldner, Doak, and Merrill (4). Six of our CRF patients were studied before and after at least 6 wk of chronic hemodialysis, $12-18 \mathrm{~h} / \mathrm{wk}$. In five patients, hemodialysis resulted in a marked improvement in glucose tolerance and the exaggerated response of plasma insulin to a glucose load disappeared (Fig. 4). The remaining patient (E. K.), a diabetic, failed to show improvement in glucose disappearance and in contrast to nondiabetic patients with $\mathrm{CRF}$ after chronic hemodialysis, plasma insulin concentrations paradoxi-
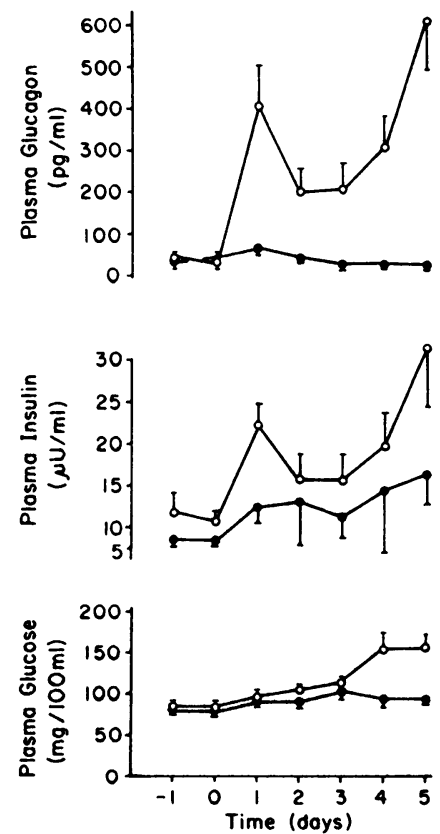

Figure 5 Bilateral ureteral ligation was accomplished in six dogs (open circles) and three dogs served as shamoperated controls (closed circles). Operative procedures were performed under sterile conditions on the day zero, 
cally rose. Elevated plasma concentrations of glucagon persisted in all patients despite adequate hemodialysis (Fig. 4). One patient (P. S.) responded to hypoglycemia $(34 \mathrm{mg} / 100 \mathrm{ml}$ ) with a sharp rise in plasma glucagon artificially elevating the mean values at 90 and 120 min (Fig. 4). Improvement of carbohydrate intolerance after hemodialysis could not be correlated with changes in plasma $\mathrm{GH}$ concentration.

\section{Results of animal studies}

The effect of bilateral ureteral ligation on plasma glucagon concentration in the dog is shown in Fig. 5. Normal values for serum potassium, creatinine and plasma glucose, insulin, and glucagon concentration were observed on all dogs on days minus one and zero. After the operative procedure on day zero, these values remained normal in sham-operated animals. In contrast, dogs undergoing ureteral ligation showed a marked rise in plasma glucagon to a mean value of $617 \pm 124 \mathrm{pg} / \mathrm{ml}$, SEM, on the fifth postoperative day. Before death on the 5th or 6th postoperative day, each animal demonstrated hyperglycemia and hyperkalemia.

Creatinine $(0.156 \mathrm{~g} / \mathrm{kg}$ in $500 \mathrm{ml}$ of saline) or urea $(2.5 \mathrm{~g} / \mathrm{kg}$ in $500 \mathrm{ml}$ of distilled water) were administered as an intravenous infusion over $3 \mathrm{~h}$ into two groups of six dogs each. The peak concentration of serum urea nitrogen and creatinine occurred at 180 $\mathrm{min}$ and were $148 \pm 12$ and $18.7 \pm 3.3 \mathrm{mg} / 100 \mathrm{ml}$, SEM. respectively. The response of immunoreactive glucagon (IRG) to these interventions was either bidirectional or absent. The respective plasma glucagon concentrations at $180 \mathrm{~min}$ were $75 \pm 28$ during urea and $154 \pm 43 \mathrm{pg} / \mathrm{ml}$, SEM, during creatinine infusion. Neither these nor any intermediate mean plasma glucagon concentrations were significantly different from control levels $(45 \pm 5.8$ [urea dogs] and $97 \pm 9.8$ [creatinine dogs]).

Analysis of uremic plasma for possible substances interfering with assay of IRG

Hyperglucagonemia in uremic patients persisted after intravenous glucose despite a normal pattern of suppression. Furthermore, hyperglucagonemia persisted after dialysis despite improved glucose tolerance. Consequently, the possibility was considered that a factor(s) might be present in uremic plasma which could interfere with the IRG assay.

$1.8 \mathrm{ml}$ of plasma from patient P. S. was chromatographed on Bio-Gel P-10 (Bio-Rad Laboratories, Richmond, Calif.). $90 \%$ of the immunoreactivity was recovered in the eluates, more than $80 \%$ of which eluted in the $3,500 \mathrm{~mol} w \mathrm{wt}$ region as marked by $\left[\mathrm{I}^{125}\right]$ glucagon. Only trace amounts of IRG eluted in the void volume where nondialysable interfering factors or proteolytic activity would be expected to elute. The remaining IRG eluted apparently as proglucagon. Therefore in this plasma, which demonstrates the highest fasting glucagon level observed in these studies, there was no evidence for the existence of any interfering substance.

Plasma from four CRF patients before and after intratvenous glucose was pooled $(380 \mathrm{pg} / \mathrm{ml}$ base line pool. $210 \mathrm{pg} / \mathrm{ml}$ postglucose pool). The IRG readings after charcoal treatment $\left(500 \mathrm{mg}\right.$ Norit- $\left.\mathrm{A}^{2} / \mathrm{ml}\right)$ were $70 \mathrm{pg} /$ $\mathrm{ml}$ and $26 \mathrm{pg} / \mathrm{ml}$, respectively. Therefore the residual glucagon immunoreactivity after i.v. glucose is readily adsorbed by charcoal and is most probably intact glucagon. The fact that the charcoal-treated plasma pools did not read zero was anticipated and was considered to be the effect of residual charcoal dust which is always present even after repeated centrifugation.

Plasma from seven uremic patients was assayed at $1: 2,1: 4$, and $1: 8$ dilutions and proportional dilution was observed in each case, adding further evidence against the presence of nonspecific interfering substances.

Finally, urea and creatinine in concentrations far in excess of those found in uremic plasma had no effect on the assay.

Although the possibility exists that uremic plasma may interfere with quantitation of IRG, the weight of evidence strongly favors the conclusion that if such an effect exists, it must be negligible.

\section{DISCUSSION}

The data reported herein confirm certain previously reported chemical and hormonal responses to intravenous glucose administration in patients with CRF. These include: (a) normal glucose and insulin concentration in plasma during fasting; $(b)$ delayed glucose utilization after intravenous glucose; $(c)$ an inappropriately elevated and delayed fall of plasma insulin concentration after intravenous glucose; and, frequently, $(d)$ an increased plasma concentration of $\mathrm{GH}$ which often, paradoxically, rises rather than falls during hyperglycemia.

In this report, it is shown that most patients with $\mathrm{CRF}$ have elevated fasting plasma glucagon concentration. Although the fasting level was distinctly above normal, its pattern of response to a protein meal and hyperglycemia was qualitatively normal. Thus, glucagon fell during hyperglycemia and rose after a protein meal. Nevertheless, the concentration reached during hyperglycemia remained clearly above normal. After conventional hemodialysis therapy for $6 \mathrm{wk}$, utilization of the same quantity of infused glucose was normal. Despite this change, plasma glucagon concentration remained elevated under conditions of fasting as well as hyperglycemia, thus obscuring the role of glucagon in the carbohydrate intolerance of patients with untreated $\mathrm{CRF}$.

\footnotetext{
${ }^{2}$ American Norit Co., Jacksonville, Fla.
} 


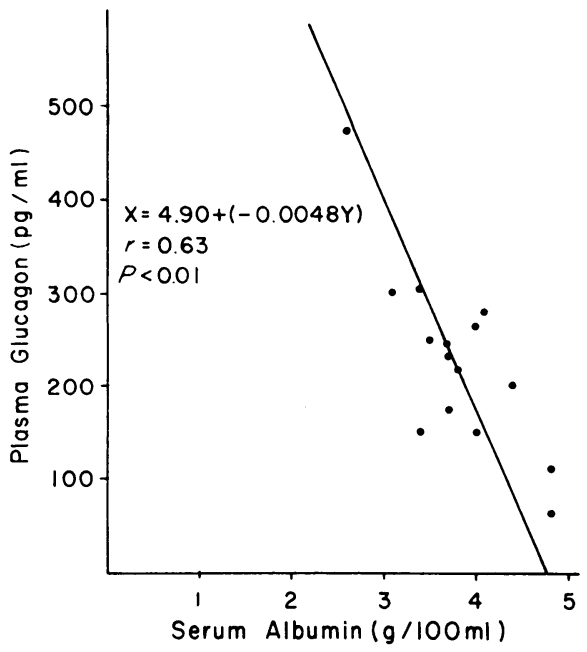

FIgure 6 Correlation of serum albumin and plasma glucagon in patients with CRF.

Compared to the studies conducted before chronic hemodialysis, five of the six patients studied again after hemodialysis showed a marked improvement of glucose utilization accompanied by decreased plasma insulin concentration in response to glucose infusion. The patient who failed to show improvement in glucose utilization and, in fact, showed a paradoxical rise in plasma insulin after hemodialysis (E. K.) was known to have maturity onset type diabetes mellitus of several years duration. The lack of improvement or even worsening of glucose utilization in diabetics who undergo hemodialysis has been reported (28).

The cause of elevated plasma glucagon concentration in renal failure is unknown. Although the possibility exists that some substance in uremic plasma interfered with the radioimmunoassay of plasma glucagon, our results suggest that this is very unlikely.

When a method employing a "single antibody technique" was used, the amounts of glucagon-like substances in uremic serum have been reported as normal (24). However, the glucagon assay utilized was probably not specific for pancreatic glucagon. Fig. 1 demonstrates a significant correlation between the concentrations of serum creatinine and plasma glucagon. It is doubtful, however, that increased plasma concentration of either creatinine or urea per se could stimulate release of pancreatic glucagon. This is supported by our inability to induce elevation of plasma glucagon concentration by infusion of these compounds in the dog.

In contrast, our studies in dogs showed that acute renal failure resulting from bilateral ureteral ligation resulted in a sharp rise in plasma glucagon concentration within $24 \mathrm{~h}$, which was not the case in sham-operated controls (Fig. 5).
The possibility was also considered that high plasma glucagon levels in uremia were related to increased tissue catabolism or malnutrition. Recently, Rocha, Santeusanio, Faloona, and Unger have demonstrated high concentrations of glucagon associated with catbolic illness such as severe infections (29). Moreover, starvation per se may be accompanied by elevated plasma glucagon concentration (30). In the absence of excessive protein loss, serum albumin concentration has been considered by most investigators to be an approximate index of protein malnutrition. With this in mind, we conpared concentration of plasma glucagon with albumin (Fig. 6) and found a significant inverse correlation $(r=0.63, P<0.001)$. Although clinically improved when compared to patients with chronic untreated uremia, patients sustained on chronic hemodialysis remain chronically ill. Indeed, their status is quite similar to that of patients with chronic protein malnutrition. On the other hand, the notion that chronic malnutrition might be partially responsible for uremic hyperglucagonemia is not supported by at least two other lines of evidence. First, hyperglucagonemia appeared within $24 \mathrm{~h}$ in the dog after ureteral ligation and second, it disappeared as rapidly as $48 \mathrm{~h}$ after successful renal transplantation in man. ${ }^{3}$ Thus, it was not considered likely that malnutrition per se could fluctuate as rapidly as glucagon concentration under such conditions.

The possibility that uremic hyperglucagonemia might be related to potassium was also considered. Thus, intravenous infusion of potassium chloride into the $\log$ has been shown to stimulate release of pancreatic glucagon (31). The rise of serum potassium concentration produced by ureteral ligation in logs could in part account for increased plasma glucagon concentration. However, serum potassium concentration was not an important factor in producing hyperglucagonemia in $\mathrm{CRF}$ patients since no correlation was found between serum $\mathrm{K}$ and plasma glucagon concentrations. Although it was observed in the same patients that skeletal muscle potassium content was below normal before dialysis therapy, the fact that glucagon remained elevated despite correction of muscle potassium content during chronic hemodialysis therapy (32) suggests that under these conditions, intracellular $\mathrm{K}$ concentration did not play a role in hyperglucagonemia.

Müller, Faloona, and Unger have recently suggested that the molar ratio of insulin to glucagon $(l / G)$ is often lower in patients with diabetes mellitu malnutrition, or starvation (33) and may contribute to the catabolic state so often associated with complications of diabetes, such as infection. In these patients, the ratio was comparable to that observed during starvation. Although malnutrition is often subtle in uremic patients, its assess-

\footnotetext{
${ }^{3}$ To be published.
} 
ment and assignment of significance to the $\mathrm{I} / \mathrm{G}$ ratio in patients with $\mathrm{CRF}$ was not possible from the data at hand.

\section{ACKNOWLEDGMENTS}

The technical assistance of James Long, Deloia Morris, Kay McCorkle, Virginia Harris, Margaret Bickham, Sheela Rathod, Shirley Harvey, Brenda Tower, Stafford Cassel, John Huff, James Hoback, and Russell Horn is gratefully acknowledged. The secretarial assistance of Mrs. Linda Edwards is also acknowledged.

This work was supported in part by the Veterans Administration, U. S. Public Health Service grant no. 5 PO1 HE11662, The Hoechst Pharmaceutical Company, Upjohn Pharmaceutical Company, and the Dallas Diabetes Association.

\section{REFERENCES}

1. Myers, V. C., J. A. Killian. 1917. Studies on animal diastases. I. The increased diastatic activity of the blood in diabetes and nephritis. J. Biol. Chem. 29: 179.

2. Perkoff, G. T., C. L. Thomas, J. D. Newton, J. C. Sellman, and F. H. Tyler. 1958. Mechanism of impaired glucose tolerance in uremia and experimental hyperazotemia. Diabetes. 7: 375.

3. Klink, D. D., R. C. Meade, and D. A. Roth. 1965. Insulin response to glucose in azotemia. Diabetes. 14: 459.

4. Hampers, C. L., J. S. Soeldner, P. B. Doak, and J. P. Merrill. 1966. Effect of chronic renal failure and hemodialysis on carbohydrate metabolism. J. Clin. Invest. $45: 1719$.

5. Briggs, J. D., K. D. Buchanan, R. G. Luke, and M. T. McKiddie. 1967. Role of insulin in glucose intolerance in uremia. Lancet. 1: 462 .

6. Horton, E. S., C. Johnson, and H. E. Lebovitz. 1968. Carbohydrate metabolism in uremia. Ann. Intern. Med. 68: 63 .

7. Tchobroutsky, G., G. Collin de L'hortet, G. Rosselin, R. Assan and M. Derot. 1965. Etude de la glycorégulations dans l'insussisance rénale chronique I. Diabetologia. $1: 101$.

8. Hutchings, R. H., R. M. Hegstrom, and B. H. Scribner. 1966. Glucose intolerance in patients on long-term intermittent dialysis. Ann. Intern. Med. 65: 275.

9. Gerletty, J. M., and N. H. Engbring. 1967. Azotemia and glucose intolerance. Ann. Intern. Med. 66: 1097.

10. Spitz, I. M., A. H. Rubenstein, I. Bersohn, C. Abrahams, and C. Lowry. 1970. Carbohydrate metabolism in renal disease. Q. J. Med. $39: 201$.

11. Lowrie, E. G., J. S. Soeldner, C. L. Hampers, and J. P. Merrill. 1970. Glucose metabolism and insulin secretion in uremic, prediabetic and normal subjects. J. Lab. Clin. Med. 76: 603.

12. Westervelt, F. B., Jr., and G. E. Schreiner. 1962. The carbohydrate intolerance of uremic patients. Ann. Intern. Med. $57: 266$.

13. Westervelt, F. B., Jr. 1969. Insulin effect in uremia. J. Lab. Clin. Med. 74 : 79.

14. O'Brien, J. P., and A. R. Sharpe, Jr. 1967. The influence of renal disease on the insulin $\mathrm{I}^{131}$ disappearance curve in man. Metab. (Clin. Exp.). 16: 76.
15. Cohen, B. D., and H. I. Horowitz. 1968. Carbohydrate metabolism in uraemia: inhibition of phosphate release. Am. J. Clin. Nutr. 21: 407.

16. Spergel, G., S. J. Bleicher, M. Goldberg, J. Adesman, and M. G. Goldner. 1967. The effect of potassium on the impaired glucose tolerance in chronic uremia. Metab. (Clin. Exp.). 16: 581.

17. Balestri, P. L., P. Rindi, M. Biagini, and S. Giovannetti. 1972. Effects of uraemic serum, urea, creatinine and methyl guanidine on glucose metabolism. Clin. Sci. $(O x f) .42:$.395 .

18. Alleyne, G. A. O., H. S. Fraser, and H. S. Besterman. 1970. Some effects of metabolic acidosis on carbohydrate metabolism in the rat. Clin. Sci. (Oxf.). 39: 375.

19. Unger, R. H., E. Aguilar-Parada, W. A. Müller, and A. M. Eisentraut. 1970. Studies of pancreatic alpha cell function in normal and diabetic subjects. J. Clin. Invest. $49: 837$.

20. Unger, R. H. 1971. Glucagon physiology and pathophysiology. N. Engl. J. Med. 285: 443.

21. Muller, W. A., G. R. Faloona, E. Aguilar-Parada, and R. H. Unger. 1970. Abnormal alpha-cell function in diabetes: response to carbohydrate and protein ingestion. N. Engl. J. Med. 283: 109.

22. Brown, M. E. 1961. Ultra-micro sugar determinations using 2,9-dimethyl-1,10-phenanphroline hydrochloride. Diabetes. 10: 60 .

23. Lindall, A., R. Carmena, S. Cohen, and C. Comty. 1971. Insulin hypersecretion in patients on chronic hemodialysis. Role of parathyroids. J. Clin. Endocrinol. 32: 653.

24. Glick, S. M., J. Roth, R. S. Yalow, and S. A. Berson. 1965. The regulation of growth hormone secretion. Recent Prog. Horm. Res. $21: 241$.

25. Orskov, H., and N. J. Christensen. 1971. Growth hormone in uremia. I. Plasma growth hormone, insulin and glucagon after oral and intravenous glucose in uremic subjects. Scand. J. Clin. Lab. Invest. 27: 51.

26. Samaan, N. A., and R. M. Freeman. 1970. Growth hormone levels in severe renal failure. Metab. (Clin. Exp.). $19: 102$.

27. Spitz, I., H. Rubenstein, J. Bersohn, A. M. Lawrence, and L. Kirsteins. 1970. The effect of dialysis on the carbohydrate intolerance of chronic renal failure. Horm. Metab. Res. 2: 86.

28. Ghavamian, M., C. F. Gutch, K. F. Kopp, and W. J. Kolff. 1972. The sad truth about hemodialysis in diabetic nephropathy. J. Am. Med. Assoc. 222: 1386.

29. Rocha, D. M., F. Santeusanio, G. R. Faloona, and R. H. Unger. 1973. Abnormal pancreatic alpha-cell function in bacterial infections. N. Engl. J. Med. 288: 700 .

30. Aguilar-Parada, E., A. M. Eisentraut, and R. H. Unger. 1969. Effects of starvation on plasma pancreatic glucagon in normal man. Diabetes. 18: 717.

31. Santeusanio, F., G. R. Faloona, J. P. Knochel, and R. H. Unger. 1973. Evidence for a role of endogenous insulin and glucagon in the regulation of potassium homeostasis. J. Lab. Clin. Med. 81: 809.

32. Bilbrey, G. L., N. W. Carter, M. G. White, J. F. Schilling, and J. P. Knochel. 1973. Potassium deficiency in chronic renal failure. Kidney Int. 4: 423.

33. Müller, W. A., G. R. Faloona, and R. H. Unger. 1973. Hyperglucagonemia in diabetic ketoacidosis; its prevalence and significance. Am. J. Med. 54: 52 . 